\title{
EFFECTIVENESS OF TRANSGENIC BT MAIZE TO CONTROL Helicoverpa armigera (LEPIDOPTERA: NOCTUIDAE)
}

\author{
Fernando Belezini Vinha ${ }^{1 *}$, Carlos Alberto Zambiasi², Murilo Gaspar Litholdo ${ }^{2}$, Abílio José Meiato \\ Barrionuevo Oliveira ${ }^{2}$, Alexandre De Sene Pinto ${ }^{2}$
}

\author{
${ }^{1}$ Faculdade de Ciências Agrarias e Veterinárias - FCAV/Unesp, Via de Acesso Professor Paulo Donato \\ Castelane Castellane S/N - Vila Industrial, Jaboticabal, São Paulo, Brazil CEP: 14884-900. *Fone (16) \\ 99771-8955, E-mail: fernandobevi@hotmail.com \\ ${ }^{2}$ Centro Universitário Moura Lacerda, Departamento de Agronomia, Av. Dr. Oscar de Moura Lacerda, 1520, \\ 14076-510, Ribeirão Preto, São Paulo, Brazil \\ *Autor para correspondência: Fernando Belezini Vinha, fernandobevi@hotmail.com
}

\begin{abstract}
The caterpillar Helicoverpa armigera (Hübner) (Lepidoptera: Noctuidae), identified in Brazil in 2013, greatly worries farmers because of its destructive power. The technology of transgenic plants that induces resistance to insects is a great ally for controlling caterpillars. In this study we compared the performance of transgenic Bt maize in the controlling of different larval instars of $\mathrm{H}$. armigera in semi-field seedlings. There were tested the following genotypes: (1) Non-Bt maize Iso-hybrid (Control); (2) Cry1F; (3) Cry1F+ Cry1A.105 + Cry2Ab2; (4) Cry1A.105 + Cry2Ab2; (5) Cry1Ab + Cry1F; (6) Cry1Ab + Vip3Aa20. The experimental design was organized in randomized blocks with eight replications, each consisting of a pot with 5 plants artificially infested with larvae of $2^{\text {nd }}, 3^{\text {rd }}$ or $4^{\text {th }}$ instar. At $1,3,7,10$ and 14 days after infestation, plants were evaluated for defoliation. In the $3^{\text {rd }}$ instar larvae bioassay, there was high predation by birds, but until seven days after infestation all transgenic maize were efficient to the pest. All transgenic Bt maize were effective in the control of tested $H$. armigera larvae instars.
\end{abstract}

KEY WORDS: Toxins, Zea mays, Noctuidae, Lepidoptera.

\section{EFETIVIDADE DE MILHOS TRANSGÊNICOS BT NO CONTROLE DE Helicoverpa armigera (LEPIDOPTERA: NOCTUIDAE)}

RESUMO: A lagarta Helicoverpa armigera (Hübner) (Lepidoptera: Noctuidae), identificada no Brasil em 2013, preocupa muito os agricultores por conta do seu grande poder destrutivo. A tecnologia de plantas transgênicas resistentes a insetos é uma grande aliada para manejar lagartas. Neste estudo foi comparado o desempenho de milhos transgênicos Bt no controle de diferentes ínstares larvais de $H$. armigera em plântulas em semicampo. Foram testados os seguintes genótipos: (1) milho convencional não transgênico (Controle) ; (2) Cry1F ; (3) Cry1F+ Cry1A.105 + Cry2Ab2 ; (4) Cry1A.105 + Cry2Ab2; (5) Cry1Ab + Cry1F ; (6) Cry1Ab + Vip3Aa20.O delineamento experimental foi de blocos casualizados, com oito repetições, formada por um vaso com 5 plantas infestadas artificialmente com lagartas de $2^{\circ}, 3^{\circ}$ ou 4ํ ínstar. Aos 1, 3, 7, 10 e 14 dias após a infestação as plantas foram avaliadas quanto à desfolha. No ensaio com lagartas de 3 o ínstar houve muita predação por pássaros, mas até sete dias após a infestação todos os transgênicos foram eficientes à praga. Todos os milhos transgênicos Bt foram eficazes no controle dos ínstares larvais testados de $\mathrm{H}$. armigera.

PALAVRAS-CHAVE: Toxinas, Zea mays, Noctuidae, Lepidoptera.

\section{INTRODUCTION}

In recent years, the cotton bollworm Helicoverpa armigera (Hübner) (Lepidoptera: Noctuidae), was introduced and spread throughout South America, especially in Brazil, where in recent years caterpillars of the subfamily Heliothinae have produced great damages in several crops, regardless if transgenic or not (Jones et al.,2019).

Although this pest has been considered a quarantine pest $A 1$ in Brazil, it was recently detected in the states of Goiás, Bahia and Mato Grosso, mainly associated with cotton and soybean crops (Czepak et al., 2013).
It is an extremely polyphagous pest whose larvae have been recorded in more than 60 species of wild and cultivated plants and in more than 60 host families, including Asteraceae, Fabaceae, Malvaceae, Poaceae and Solanaceae. This pest can cause serious damage to different economically important crops, such as cotton, legumes, sorghum, corn, tomatoes, ornamental plants and fruit trees (Reed, 1965; Pawar et al., 1986; Fitt, 1989; Pogue, 2004; Moral Garcia, 2006).

Besides being very polyphagous and voracious, this pest develops very fast, completing its life cycle in four to six weeks, reaching several 
generations in a year. Insect adults can fly over 1,000 $\mathrm{km}$, giving the species a large dispersibility (Fitt, 1989; Pedgley, 1985; Czepak et al., 2013). Moreover, it is a pest with several records of insecticide resistance (Mabbett et al., 1980; Maelzer \& Zalucki, 2000).

In the year 2013, maize crop was marked by high $H$. armigera outbreaks in the main producing zones, perhaps the largest ever recorded since the start of commercialization of genetically modified $\mathrm{Bt}$ maize seeds in Brazil. In some regions of the states of Mato Grosso and Mato Grosso do Sul, several maize producers also reported the occurrence of Helicoverpa $s p$. in Bt maize crops, notably in the transgenic cultivar expressing the Cry1F toxin (Ávila et al., 2013).

The Bt transgenic maize was developed with refined laboratory techniques using a gene from the entomopathogenic bacterium Bacillus thuringiensis (Bt), which was introduced into maize plants, conferring high plant resistance to some species of lepidopteran pests (Armstrong et al. al., 1995). The introduced gene encodes Bt protein expression with insecticidal action, effective in controlling lepidoptera such as Spodoptera frugiperda (J.E. Smith) (Lepidoptera: Noctuidae) (Huang et al., 2002).

However, little is known about the effect of bt toxins to $H$. armigera, in this study, the objective was to compare the performance of $\mathrm{Bt}$ transgenic maize seedlings in the control of $H$. armigera caterpillars at different instars.

\section{MATERIAL AND METHODS}

Site locations and insect pest source

Three bioassays were carried out at the Moura Lacerda University Center (Ribeirão Preto - São
Paulo state). The $H$. armigera caterpillars, used in the bioassays for artificial infestations were obtained from laboratory colonies maintained by Bug Agentes Biológicos, (Charqueada - São Paulo state). The caterpillars were kept in artificial diet described by (Hamed \& Nadeem, 2008). All insect colonies were reared on artificial diet and maintained in a room with controlled conditions of temperature $\left(25 \pm 3^{\circ} \mathrm{C}\right)$, relative humidity $(60 \pm 5 \%)$ and photoperiod (14:10 (L: D) h).

\section{Insect infestation and experimental design}

The bioassays were conducted from 6 to 23 May and June, 2016. Each biossay was installed in a semi-field, where the corn tested genotypes were sown in $15 \mathrm{~L}$ plastic pots, fertilized with $25 \mathrm{~g}$ of NPK 414-8 formulation, two days before sowing. Forty-eight vessels were used per assay and covered with voilelike tissue attached to the sides of the vessels by a sewing elastic and supported by a stake about $50 \mathrm{~cm}$ behind the vessels. The pots were kept in the open field.

All trials were carried out similarly, with the difference only in the number of caterpillars in plant infestation. Each bioassay compared five different transgenic Bt maize and one Non-Bt maize for the damage caused by 2,3 and $4 \mathrm{H}$. armigera larval instars.

The experimental design was organized in randomized blocks, where each of six treatments was repeated eight times, each repetition being a pot with five plants, spaced $10 \mathrm{~cm}$ apart. The non-Bt isogenic maize hybrid (iso-hybrid) of the same genetic background was used as control (Table 1).

Table 1. Treatments, maize hybrids with the expressed Bt proteins if applicable, and corresponding Bt events

\begin{tabular}{|c|c|}
\hline Treatments & Event(s) \\
\hline Non-Bt maize Iso-hybrid (Control) & None \\
\hline Cry1F & TC1507a \\
\hline Cry1F+ Cry1A.105 + Cry2Ab2 & TC1507 x MON89034 x NK603c \\
\hline Cry1A.105 + Cry2Ab2 & MON890349 \\
\hline Cry $1 A b+$ Cry $1 F$ & TC1507 x MON810 x N NK603 \\
\hline Cry1Ab + Vip3Aa20 & $\mathrm{Bt} 11^{e} \times \mathrm{MIR} 162^{d} \times \mathrm{TC} 1507 \times \mathrm{GA} 21^{f}$ \\
\hline
\end{tabular}

${ }^{a}$ Event TC1507 expresses Cry1F and PAT proteins. PAT protein confers glufosinate herbicide tolerance, Dow AgroSciences, Indianapolis, IN. ${ }^{b}$ Event MON810 expresses Cry1Ab + CP4EPSPS + GOXV247 proteins that confers glyphosate herbicide tolerance, Monsanto Company, St. Louis, MO. 'Event NK603 expresses CP4EPSPS protein that confers glyphosate herbicide tolerance, Monsanto Company, St. Louis, MO. ${ }^{d}$ Event MIR162 expresses Vip3Aa20 protein, Syngenta, Research Triangle Park, NC. ${ }^{e}$ Event Bt11 expresses Cry1Ab and PAT proteins. Syngenta, Research Triangle Park, NC. 'Event GA21 expresses MEPSPS protein that confers tolerance to glyphosate herbicides, Monsanto Company, St. Louis, MO. ${ }^{9}$ Event MON 89034 expresses Cry1A.105 + Cry2Ab2 proteins, Monsanto Company, St. Louis, MO.

In the first and second bioassays, six days after seedling emergence, $a 2^{\text {nd }}$ and $4^{\text {th }}$ caterpillar instar, respectively, was placed between the leaves of each plant. In the third bioassay, four days after emergence, $3^{\text {rd }}$ caterpillar's instar were infested on seedlings. All plants were evaluated for the average defoliation percentage $1,3,7,10$ and 14 days after infestation. 


\section{Statistical analysis}

All data were submitted to analysis of variance (ANOVA). When the F-test of ANOVA indicated a significance of $5 \%$ of error probability, the complementary analyzes were carried out by means of the Tukey test at $5 \%$ of probability, where the averages were compared. All statistical calculations were performed by the program Statistica for Windows (Statsoft, 1996).

\section{RESULTS AND DISCUSSION}

In the bioassay where the $2^{\text {nd }}$ instar larvae of Helicoverpa armigera were artificially infested in the different maize genotypes, significant differences were found between treatments.

All Bt transgenic maize presented the lower average defoliation percentages compared to non-Bt treatment, every day after infestation. Only at 14 days after infestation did the Cry1F treatment show a greater defoliation than the Cry1F + Cry1A.105 + Cry2Ab2 treatment, both differing statistically from the others Bt genotypes (Figure 1).

Figure 1. Average defoliation percentage of $\mathrm{Bt}$ and non-Bt maize seedlings after artificial infestation with $2^{\text {nd }}$ instar of Helicoverpa armigera caterpillars. Points values followed by different letters were significantly different by Tukey's test $(p \leq 0.05)$.

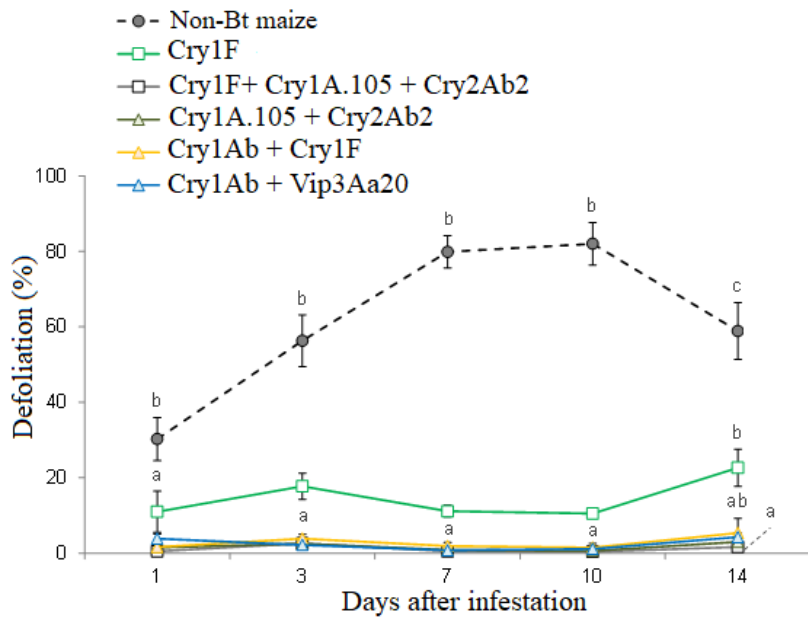

At 14 days after infestation, the defoliation average percentage in non-Bt maize was $58.88 \pm$ $7.54 \%$, in Cry $1 \mathrm{~F}$ transgenic maize $22.63 \pm 4.95 \%$ and in the other transgenic defoliation ranged from $1.63 \pm$ 1.26 (Cry1F + Cry1A.105 + Cry2Ab2) to $5.38 \pm 3.82 \%$ (Cry1Ab + Cry1F).

When $3^{\text {rd }}$ instar caterpillars were infested on maize, all transgenics suffered significantly less defoliation than non-Bt maize, until seven days after infestation. At 10 days, there were no differences between treatments. At 14 days after infestation, only Cry1A.105 + Cry2Ab2 treatment differed from non-Bt treatment, presenting the lowest defoliation average percentage value (Figure 2).

Figure 2. Average defoliation percentage of $\mathrm{Bt}$ and non-Bt maize seedlings after artificial infestation with $3^{\text {rd }}$ instar of Helicoverpa armigera caterpillars. Points values followed by different letters were significantly different by Tukey's test $(p \leq 0.05)$.

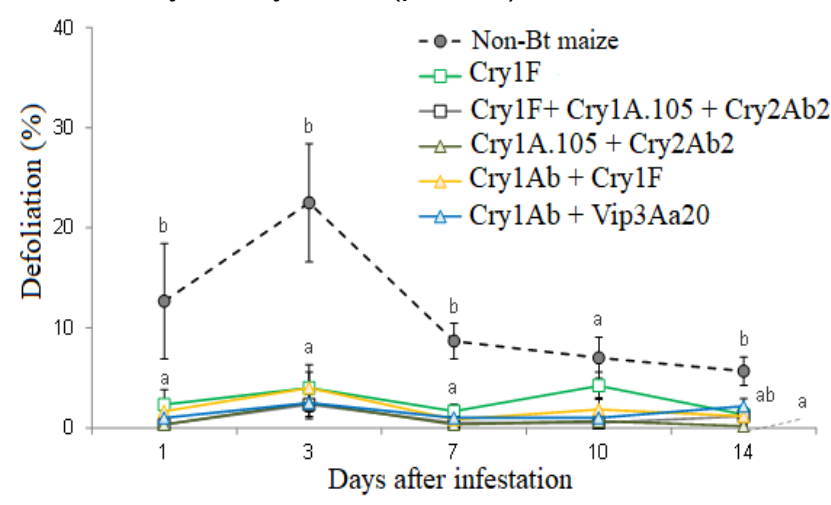

In this bioassay there was too much predation of caterpillars by birds, which perforated the "voil" protection for capture. This must have interfered with the results, not allowing a safe conclusion about $3^{\text {rd }}$ instar caterpillar. However, the first evaluations show a tendency of all transgenic maize to be effective to H. armigera.

In the assay of $4^{\text {th }}$ instar caterpillars, all transgenic maize differed from the non-Bt treatment, which presented the highest defoliation average value on all dates (Figure 3 ).

Figure 3. Average defoliation percentage of $\mathrm{Bt}$ and non-Bt maize seedlings after artificial infestation with $4^{\text {th }}$ instar of Helicoverpa armigera caterpillars. Points values followed by different letters were significantly different by Tukey's test $(p \leq 0.05)$.

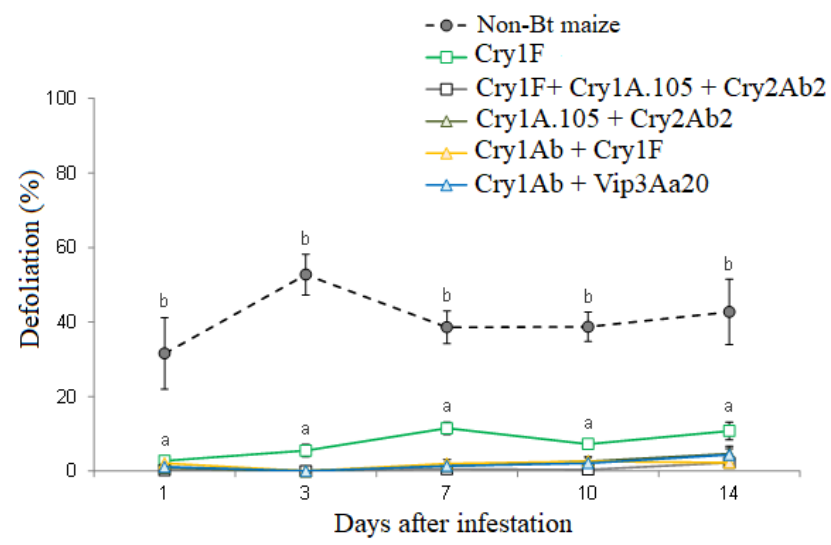

The defoliation average percentage reached $42.71 \pm 8.78 \%$ in non-Bt maize 14 days after infestation, while in transgenic maize ranged from $2.25 \pm 1.17$ (Cry $1 \mathrm{Ab}+$ Cry $1 \mathrm{~F})$ to $10.75 \pm 2.40 \%$ (Cry 1 F). Vilella et al. (2002), Siebert et al. (2008) and Santos et al. (2009) also verified the efficiency of Bt 
transgenic maize expressing Cry $1 \mathrm{Ab}$ and Cry1F toxins to Elasmopalpus lignosellus and Spodoptera cosmioides larvae under laboratory. Similar results were achieved by Liao et al. (2002), where just Cry1Ab, Cry2Ab, and Vip3A controlled $H$. armigera larvae. Avilla et al. (2005) also reported that the toxin Cry2Ab2 produced a significant growth inhibition against neonate larvae of $H$. armígera.

All $\mathrm{Bt}$ transgenic maize used in this study were effective in reduce defoliation by all $H$. armigera larval instars tested. The transgenic $\mathrm{Bt}$ maize expressing Cry1F, Cry1F + Cry1A.105 + Cry2Ab2, Cry1A.105 + Cry2Ab2, Cry1Ab + Cry1F and Cry1Ab + Vip3Aa20 toxins are efficient to control $2^{\text {nd }}, 3^{\text {rd }}$ and $4^{\text {th }}$ instar of $H$. armigera in the seedling phase.

\section{ACKNOWLEDGEMENTS}

This research was supported by the companies Corteva and Bug Agentes Biológicos. We would also like to show our gratitude to Moura Lacerda University for the area ceded to this study.

\section{REFERENCES}

Ávila, C.J.; Vivan, L.M.; Tomquelski, G.V. Ocorrência, aspectos biológicos, danos e estratégias de manejo de Helicoverpa armigera (Hübner) (Lepidoptera: Noctuidae) nos sistemas de produção agrícolas. Dourados: Embrapa Agropecuária Oeste. 2013,1.

Avilla, C.; Vargas-Osuna, E.; González-Cabrera, J.; Ferré, J.; González-Zamora, J.E.. Toxicity of several $\delta$-endotoxins of Bacillus thuringiensis against Helicoverpa armigera (Lepidoptera: Noctuidae) from Spain. Journal of Invertebrate Pathology, 2005, 90, 51-54.

Czepak, C.; Albernaz, K.C.; Vivan, L.M.; Guimarães, H.O.; Carvalhais, T. Primeiro registro de ocorrência de Helicoverpa armigera (Hübner) (Lepidoptera: Noctuidae) no Brasil. Pesquisa Agropecuária Tropical, 2013,43,110-113.

Czepak, C.; Vivan, L.M.; Albernaz, K.C. Praga da vez. Cultivar: grandes culturas, 2013, 15, 20-27.

Hamed,M.; Nadeem, S. Rearing of Helicoverpa armigera (Hub.) on artificial diets in laboratory. Pakistan Journal of Zoology, 2008, 40,447-450.

Huang, F.; Buschman, L.L.; Higgins, R.A.; Li, H. Survival of Kansas dipel-resistant European corn borer (Lepidoptera: Crambidae) on Bt and non-Bt corn hybrids. Journal of Economic Entomology, 2002, 95, 614-621.
Jones, C.M; Parry, H; Tay, W. T; Reynolds, D. R; Chapman, J.W. Movement Ecology of Pest Helicoverpa: Implications for Ongoing Spread. Annual Review of Entomology, 2019, 64, 277-295.

Llao, C.; Heckel,D.G.; Akhurst,R. Toxicity of Bacillus thuringiensis insecticidal proteins for Helicoverpa armigera and Helicoverpa punctigera (Lepidoptera: Noctuidae), major pests of cotton, Journal of Invertebrate Pathology, 2002, 80, 55-63.

Maelzer, D.; Zalucki, M. Long range forecasts of the numbers of Helicoverpa punctigera and $H$. armigera (Lepidoptera: Noctuidae) in Australia using thesouthern oscillation index and the sea surface temperature. Bulletin of Entomological Research, 2000, 90, 133-146.

Moral Garcia, F.J. Analysis of the spatial temporal distribution of Helicoverpa armigera (Hübner) in a tomato field using a stochastic approach. Biosystems Engineering, 2006, 93, 253-259.

Pogue, M.G. A new synonym of Helicoverpa zea (Boddie) and differentiation of adult males of $\mathrm{H}$. zea and $\mathrm{H}$. armigera (Hübner) (Lepidoptera: Noctuidae: Heliothinae). Annals of the Entomological Society of America, 2004, 97, 1222-1226.

Santos, K.B.;Neves ,P.; Meneguim,A.M.; Santos,R.B.; Santos,W.J.; Boas,G.V.; Dumas,V.; Martins,E.; Praça,L.B.;Queiroz,P.; Berry,C.; Monnerat, R. Selection and characterization of the Bacillus thuringiensis strains toxic to Spodoptera eridania (Cramer), Spodoptera cosmioides (Walker) and Spodoptera frugiperda (Smith) (Lepidoptera: Noctuidae). Biological Control, 2009, 50, 2, 157-163.

Siebert, S.W.; Babock, J. M.; Nolting, S.; Santos, A. C.; Adamczyk Jr., J. J.; Neese, P. A.; King, J. E.; Jenkins, J. N.; McCarty, J.; Lorenz, G. M.; Fromme, D. D.; Lassiter, R. B. Efficacy of Cry $1 f$ insecticidal protein in maize and cotton for control of Fall Armyworm (Lepidoptera: Noctuidae). Florida Entomologist, 2008, 91, 555-565.

Statsoft. Statistica for Windows: computer program manual. Tulsa, OK: StatSoft Inc., 1996.

Vilella, F.M.F.; Waquil, J. M.; Vilela, E. F.; Siegfried, B. D.; Foster, J. E. Selection of the fall armyworm, Spodoptera frugiperda (J. E. Smith) (Lepidoptera: Noctuidae) for survival on Cry $1 \mathrm{~A}(\mathrm{~b}) \mathrm{Bt}$. toxin. Revista Brasileira de Milho e Sorgo, 2002, 1, 12-17. 